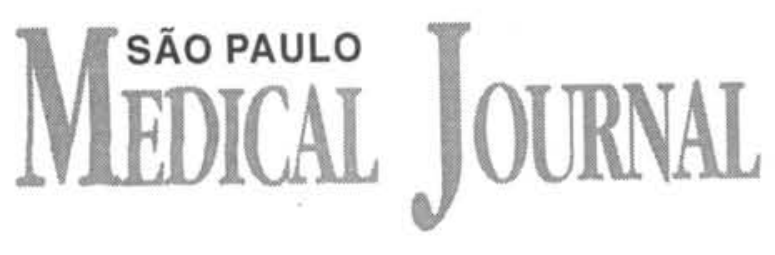

\title{
Medical treatment of cardiac arrhythmias in Chagas'heart disease
}

\author{
Clinical Cardiac Electrophysiology, Escola Paulista de \\ Medicina - São Paulo, Brazil
}

There are no controlled clinical trials evaluating drug therapy in patients with ventricular arrhythmias and chronic chagasic cardiomyopathy. Empirical treatment with disopyramide $(400-1,000 \mathrm{mg} / \mathrm{d})$, phenytoin $(4-6 \mathrm{mg} / \mathrm{d})$, mexiletine $(600-1,200 \mathrm{mg} / \mathrm{d})$, propafenone $(900 \mathrm{mg} / \mathrm{d})$, amiodarone ( loading: $1,000 \mathrm{mg} / \mathrm{d}, 10-14$ days; maintenance $200-600 \mathrm{mg} / \mathrm{d}$ ), and sotalol (320 $\mathrm{mg} / \mathrm{d}) \mathrm{had}$

efficacy and tolerance ranging from $18 \%$ to $90 \%$ with heterogeneous criteria for efficacy definition. Further studies with homogenous criteria are required to determine which is the most appropriate drug therapy for patients with chronic chagasic cardiomyopathy and ventricular arrhythmias.

UNITERMS: Chronic chagasic cardiomyopathy. Cardiac arrhythmia. Antiarrhythmic drugs.

\section{INTRODUCTION}

$\mathrm{T}$ he objectives of the treatment of cardiac arrhythmias are relief of symptoms and prevention of sudden cardiac death. The therapeutic algorithms are born from controlled clinical studies, where

\author{
Address for correspondence: \\ Angelo Amato V. de Paola \\ Setor de Eletrofisiologia Clínica \\ Escola Paulista de Medicina \\ Rua Napoleão de Barros, 593 \\ São Paulo - SP - Brasil - CEP 04024-002
}

efficacy and tolerance of these drugs are conveniently tested in human beings. These information do not have the mistakes originated from clinical reasoning.

The results of controlled clinical trials have important influence in scientific community, sometimes demonstrating that decisions guided only by clinical intuition can be dangerous to the patients. A well-known example occurred during the CAST study. It was demonstrated that patients treated with class IC antiarrhythmic drugs, which are potent antiarrhythmic agents for ventricular arrhythmias, had two to threefold increase in the number of deaths when compared with those who received placebo (28).

The majority of these studies derived from patients with ischemic cardiomyopathy after myocardial infarction. Unfortunately, there are few relevant studies in our country 
evaluating patients with Chagas' disease when the use of an antiarrhythmic drug is to be considered.

\section{CLASS I ANTIARRHYTHMIC DRUGS}

Group IA drugs: Only procainamide, quinidine and disopyramide are commercially available in Brazil. There are no adequate studies evaluating the use of such drugs in Chagas' disease.

Slow-release procainamide is not available in Brazil. Given intravenously, it is useful during an episode of sustained ventricular tachycardia. A total dose of $20 \mathrm{mg} /$ $\mathrm{Kg}$ is administered at an infusion rate of $50 \mathrm{mg} / \mathrm{min}$.

Quinidine, is commercially available in $200 \mathrm{mg}$ tablets for oral administration every 6 hour, in doses of $800-1,600 \mathrm{mg} /$ day. It reduces premature ventricular beats in $36-70 \%$ of the patients.

Disopyramide is commercially available in 100 and $250 \mathrm{mg}$. Drug discontinuation is mandatory in $9 \%$ of the patients due to symptomatic bradyarrhythmias $(1,22)$. Worsening of congestive heart failure, a condition very common in chagasic cardiomyopathy, limits its use in patients with ventricular dysfunction (19).

Group IB drugs: Lidocaine, mexiletine, and phenytoin are commercially available in our country. When intravenous administration is imperative and the ventricular arrhythmia is not responsive to procainamide, lidocaine can be used. The loading dose is $1-2 \mathrm{mg} / \mathrm{kg}$ and the maintenance dose ranges from 20 to $60 \mathrm{mcg} / \mathrm{kg} / \mathrm{min}$. Mexiletine is available in tablets of $200 \mathrm{mg}$, and the daily doses ranges from 600 to $1,200 \mathrm{mg}$ divided in 3 times doses. Premature ventricular complex suppression was achieved in $32 \%-69 \%$ but $19 \%$ of these patients had side effects $(14,15,27)$. Phenytoin is given orally, in doses of $4-6 \mathrm{mg} /$ $\mathrm{kg} /$ day ( 3 times daily) and efficacy was demonstrated in $18 \%$ of 11 patients tested (27).

Group IC Drugs: Flecainide and encainide were described as potent suppressers of premature ventricular beats (2). However, a subsequent multicentric trial showed that these drugs should not be administered in patients with poor left ventricular function $(9,28)$. Propafenone, another IC drug, is utilized orally ( $900 \mathrm{mg} /$ day), 3 times daily with efficacy and tolerance in $41 \%-66 \%(5,20)$.

It is important to stress that metanalysis of controlled studies of group I drugs in patients with ischemic cardiomyopathy delineated an increase in mortality in patients treated with these drugs when compared with a placebo group (29). Their use in chagasic cardiomyopathy, is indicated only to relief symptoms in selected cases.

\section{CLASS II ANTIARRHYTHMIC DRUGS}

In spite of being the most effective drugs in preventing sudden cardiac death (29), the beta blocker have only moderate efficacy in controlling ventricular arrhythmias (39-56\%). There are no clinical studies with these drugs in Chagas' disease: alterations in automatism, conduction and left ventricular dysfunction, will restrict the use of these drugs only for selected cases.

\section{CLASS III ANTIARRHYTHMIC DRUGS}

Experimental data and results of clinical studies changed the trends of using sodium channel blocker (class I drugs) to drugs that prolong the repolarization time (class III drugs). At the present time, there is not a drug with exclusive class III action in clinical use. Amiodarone, a drug with multiple actions, and sotalol, a non selective beta blocker, have potent class III action, and are included in this group.

Amiodarone has been empirically used in our country in all kinds of arrhythmias. Unfortunately there are no controlled studies evaluating efficacy of this drug in chagasic cardiomyopathy. In non-controlled studies, the number of premature ventricular beats decreased in 35 $92 \%$ of the patients evaluated with few side effects $(3,4,13,21)$. The doses utilized in the majority of studies varied from 600 to $1,200 \mathrm{mg}$ for 14 days (loading phase), followed by a medium doses of $400 \mathrm{mg}$ (maintenance phase).

Patients with chronic chagasic cardiomyopathy and sustained ventricular tachycardia are at major risk for sudden death. In our experience, criteria of efficacy according to Holter monitoring was found in 52\% of patients. When electrophysiologic study was used to assess efficacy, ventricular tachycardia was not reinducible in $18 \%$ of the patients (11). None of these methods was able to predict clinical efficacy of this drug. The worst prognosis during amiodarone therapy was observed in patients with congestive heart failure $(6,24)$.

Sotalol, another class III antiarrhythmic drug, also has a beta-blocker action, had better efficacy and tolerance than class I drugs (16). This drug was recently reintroduced in our country, and we observed $67 \%$ efficacy in 14 patients with Chagas' disease and sustained ventricular tachycardia refractory to drug therapy (12). Like amiodarone, its use must be extremely cautious in patients with bradyarrhythmias. 
Finally, it is important to stress that ventricular function is the most important clinical variable influencing the prognosis of patients with Chagas' disease and complex ventricular arrhythmias $(17,18)$. Patients with refractory ventricular arrhythmias, specially sustained ventricular tachycardias can be studied with the electrophysiological (7) techniques. Surgical (26) or catheter ablation (10) of an arrhythmogenic focus of ventricular tachycardia and implantation of a cardioverter-defibrillator can be indicated in patients refractory to all therapeutic options (8).

\section{Resumo}

Apesar da grande importância da cardiopatia chagásica em nosso meio, não existem estudos clínicos controlados que avaliem adequadamente as opçōes terapêuticas nessa patologia. Foram testadas disopiramida (400-1.000 mg/dia), difenilhidantoína (4-6 mg/kg/dia), mexiletine (600-1.200 mg/d), propafenona (900 mg/d), amiodarona (impregnação: $1.000 \mathrm{mg} / \mathrm{dia} /$ 10-14 dias; manutenção: 200-600 mg/d) e sotalol (320 mg/dia) com níveis de eficácia e tolerância variando de 18 a $90 \%$ dependendo das definiçōes empregadas. Estudos comparativos controlados poderão esclarecer futuramente as melhores estratégias farmacológicas para o tratamento dessa entidade nosológica.

\section{REFERENCES}

1. ALBANESIFILHO, F.M.; DA ROCHA.P.J.; BENCHIMOL, C.B.; GINEFRA, P. \& BENCHIMOL, A.B. - Disopiramida no tratamento da extra-sistolia ventricular da cardiopatia chagásica crônica. Arq Bras Cardiol 33: 453-8, 1979.

2. CAPS investigators - The cardiac arrhytmia pilot study, Am J Cardiol 57: 91-5, 1986.

3. CARRASCO, H.A.; VICUNA, A.V.; MOLINA, C. et al. Effect of low oral doses of disopyramide and amiodarone on ventricular and atrial arrhytmias of chagasic patients with advanced myocardial damage. Int J Cardiol 9: 425-38, 1985.

4. CHIALE, P.; HALPERN, S.; NAU, G.J. et al. - Efficacy of amiodarone during long-term treatment of malignant ventricular arrhytmias in patients with chronic chagasic myocarditis. Am Heart J 107: 656-65, 1984.
5. DA SILVA, M.A.D.; FRAGATA FILHO, A.A.; BOAINAIN, E. \& MAGALHÃES, H.M. - Avaliação da propafenoma em pacientes chagásicos com extra-sistolia ventricular. Arq Bras Cardiol 36: 437-40, 1981.

6. DE PAOLA, A.A.V.; HOROWITZ, L.; SPIELMAN, S.R. et al. - Development of congestive heart failure and alterations in left ventricular function in patients with sustained ventricular tachyarrhythmias treated with amiodarone. Am J Cardiol 60: 276-80, 1987.

7. DE PAOLA, A.A.V.; HOROWITZ, L.N.; MIYAMOTO, M.H. et al. - Angiographic and electrophysiologic substrates of ventricular tachycardia in chronic chagasic myocarditis. Am J Cardiol 65: 360-3, 1990.

8. DE PAOLA, A.A.V.; HOROWITZ, L.N.; MIYAMOTO, M.H. et al. - Angiographic and electrophysiologic substrates of ventricular tachycardia in chronic chagasic myocarditis. Am Heart J 118: 415-7, 1989. 
9. DEPAOLA, A.V.V.; HOROWITZ, L.N.; MORGANROTH, J. et al. - Influence of left ventricular dysfunction on flecainide theraphy. J Am Coll Cardiol 9: 163-8, 1987.

10. DE PAOLA, A.A.V.; GOMES, J.A.; SOUZA, I.A.; PINHEIRO, R.; GUIGUER JR, N. \& MARTINEZ FILHO, E.E. - Localization of the site of the origin of sustained ventricular tachycardia in chronic chagasic cardiomyopathy. PACE 16: 871, 1993.

11. DE PAOLA, A.A.V.; GOMES, J.A.; SOUZA, I.A.; VATTIMO, A.C.; GUIGUER JR, N. \& MARTINEZ FILHO, E.E. - Efficacy of amiodarone in patients with ventricular tachycardia and chronic chagasic cardiomyopathy. J Am Coll Cardiol 23 (Suppl): 322A, 1994.

12. GONDIN, F.A.A.; DE PAOLA, A.A.V.; SILVA, R.M.F.L.; METHA, N. \& MARTINEZ FILHO, E.E. - Eficácia e tolerância do sotatol em pacientes com taquiarritmias ventriculares sustentadas. Arq Bras Cardiol 62: 64, 1994.

13. GRECO, O.T.; LORGA, A.M.; GARZON, S.A.C. et al. - A amiodarona nas arritmias ventriculares da cardiopatia chagásica crônica. Arq Bras Cardiol 35: 177-81, 1980.

14. JURADO, A.Z. \& DE FEUILADE, N.D. - Empleo del mexiletine en las arritmias ventriculares de la cardiopatia chagasica. Prensa Med Argent 73: 665-73, 1986.

15. LORGA, A.M.; GRECO, O.T.; GARZON, S.A.C. et al. Mexitil no tratamento de arritmias ventriculares de cardiopatas chagásicos crônicos. Rev Bras Med (Cardiologia) 2: 47-52, 1983.

16. MASON, J.W. - For the ESVEM investigators. A comparison of seven antiarrhythmie drugs in patients with ventricular tachyarrhythmias. N Engl J Med 329: 452-8, 1993.

17. NETTO, O.S.; DE PAOLA, A.A.V.; MENDONÇA, A. et al. - Fatores relacionados com a ocorrência de taquicardia ventricular ou óbito em pacientes portadores de cardiopatia chagásica crônica. Arq Bras Cardiol 61: 19, 1993.

18. PINHEIRO, R.; DE PAOLA, A.A.V.; MIYAMOTO, M.H. et al. - Morte súbita em pacientes com cardiopatia chagásica crônica e taquicardia ventricular não sustentada. Arq Bras Cardiol 57: 134, 1991.

19. PODRID, P.J.; SCHOENENBERGER, A. \& LOWN, B. Congestive heart failure caused by oral disopyramide. N Engl J Med 302: 614-7, 1980.

20. PORTO, C.C.; GUIMARÃES, E.; ROSA, J. \& RASSI, A. Propafenoma na prevenção das extra-sístoles ventriculares de etiologia chagásica relacionadas com o esforço físico. Avaliação por circloergometria. Arq Bras Cardiol 39: 129 33,1982 .

21. PRATA, A.P.; BATISTA, E.P. \& PENHALVER, J.R. - Uso de amiodarona em arritmias cardíacas de chagásicos crônicos. F Med(BR) 85: 713-7, 1982.

22. RASSI, A. \& PERINI, G. - Ensaio cego com disopiramida no tratamento de extra-sistolia ventricular da cardiopatia chagásica crônica controlado através do sistema Holter de eletrocardiografia dinâmica. Arq Bras Cardiol 41: 72, 1983.

23. ROSENBAUM, M.; POSSE, R.; SGAMMINI, H. et al. Estudio clinico multicentrico comparativo de la flecainida y la amiodarona en el tratamiento de las arritmias ventriculares asociadas a la cardiopatia chagasica cronica. Arch Inst Cardiol Mex 57: 325-30, 1987.

24. SCANAVACCA, M.I.; SOSA, E.A.; LEE, J.H.; BELLOTTI, G. \& PILEGGI, F. - Terapêutica empírica com amiodarona em portadores de miocardiopatia chagásica crônica e taquicardia ventricular sustentada. Arq Bras Cardiol 54: 367-71, 1990.

25. SGAMMINI, H.O.; EVEQUOZ, M.C.; CHUIT, R.; ATTI, R.; SANTAMARINA, N.O. \& KUSCHNIR, E. - Tratamiento de las arritmias de alto riesgo de muerte subita en la cardiopatia chagasica cronica con mexiletine oral. Evaluacion con monitoreo electrocardiografico ambulatorio de $24 \mathrm{~h}$ (Holter). Arq Bras Cardiol 40: 103-9, 1983.

26. SOSA, E.; BARBERO, M.; SCALABRINI, A.; BELLOTTI, G.; JATENE, A. \& PILEGGI, F. - Surgical treatment of recurrent ventricular tachycardia in chronic chagasic heart disease. (Abstractr book) Washington: X World Congress of Cardiology 1986. 117 p.

27. SUAREZ-KURTZ, G.; LORGA, A.M. \& MORAES, F.D. Effects of phenytoin on the ventricular tachyarrhythmias of chronic Chagas'disease. Int J Cardiol 36: 81-6, 1992.

28. The Cardiac Arrhytmia Suppression Trial (CAST) Investigators - Effect of encainide and flecainide on mortality in a randomized trial of arrhythmia suppression after myocardial infarction. N Eng J Med 321: 406-12, 1989.

29. YUSUF, S.; VENKATECH, G. \& TEO, K.K. - Critical review of the approaches to the prevention of sudden death. Am J Cardiol 72: 51-8, 1993. 